\title{
A kisgyermeknevelö-gyermek interakciók megfigyelésével kapcsolatos kihívások
}

\section{GYÖNGY KINGA}

Eötvös Loránd Tudományegyetem, Tanító- és Óvóképző Kar

\begin{abstract}
Számos tudományban, köztük az etológiában, fejlödéslélektanban, illetve a kisgyermeknevelésben is alkalmazzák a megfigyelést mint adatgyüjtési technikát. Ez az irás a kisgyermekek és nevelöik-gondozóik közti interakciók megfigyeléséröl szól, ezen belül áttekintjük a megfigyelés (1) klinikai/terápiás, (2) kisgyermeknevelési/pedagógiai és (3) kutatási célú felhasználási lehetöségeit. Végezetül ismertetjük, hogy a kutatási célú megfigyelési kódrendszerek összeállitása milyen lépéseken keresztül zajlik. Áttekintjük a leggyakoribb buktatókat, és leírjuk, hogyan kerülhetök el a megfigyeléses adatok kódolásának nehézségei. Noha a módszer idó- és energiaigényes, a megfigyelés révén részletgazdag és pontos információhoz jutunk a kisgyermekekröl, és gondozóikkal való interakcióikról. Mindezek miatt az interakciók megfigyelése megkerülhetetlen.
\end{abstract}

Kulcsszavak: megfigyelés, interakció, kutatásmódszertan, kisgyermeknevelés, kódolás

\section{Bevezetés}

Mint ahogy Martin és Bateson (2007) írják a megfigyelésről szóló tankönyvük elején „Azok, akik még sosem próbálkoztak a viselkedés mérésével, karosszékük biztonságából feltételezhetik, hogy a feladat könnyü és egyértelmű, melyhez nem szükséges különleges tudás vagy készség. Hiszen csak leírjuk, ami történik! Ezzel éles ellentétben, akik a viselkedés szisztematikus mérésével első ízben próbálkoznak, visszariadnak a feladat bonyolultságától. Hogy fogják észrevenni mindazt, ami történik? A rögzítés kihívásairól nem is szólva... Az igazság az, hogy a viselkedés megfigyelése egy készség, melyet nem különösebben nehéz elsajátítani, ha ismerjük az alapelveket és tisztában vagyunk a buktatókkal." (Martin \& Bateson, 2007. 1. o., ford.: Gy. K.) Tehát a laikus felfogással szemben a szisztematikus megfigyelés készsége tanulás eredménye.

Onnan is látszik, hogy a megfigyelést gyakorolni kell, hogy a kezdő megfigyelők tipikus hibákat vétenek. Sokszor nem tudják, mely viselkedéselemeket rögzítsék és milyen részletességgel. Egyesek nem képesek a viselkedés objektív leírása és interpretációja közti különbségtételre, vagy szakmai véleményüket belekeverik a viselkedés leírásába. Ezek a hibák megakadályozzák, hogy a megfigyelés révén választ kaphassunk kérdéseinkre, illetve a köznapi megfigyeléseink szintjére degradál- ják a tudományos módszert.

A megfigyeléssel kapcsolatos további félreértéseket jól tükrözi az is, hogy az egyetemi szakdolgozók fel szokták tenni a kérdést, hogy a megfigyelés helyett vagy mellett nem lenne-e szükség valamilyen „rendes” kutatási módszerre (pl. kérdőívezésre vagy interjúra).

Ha a pszichológiai kutatási trendeket vizsgáljuk, akkor elmondható, hogy a papír-ceruza tesztekhez vagy egyéb eljárásokhoz képest kutatói körökben is inkább mellőzött módszer a megfigyelés. Egy 2010-ben publikált vizsgálat szerint az angol nyelvű, 2000 és 2007 közt készült iskolapszichológiai témájú doktori diszszertációk (N=1119) közt a természetes megfigyelést alkalmazó disszertációk aránya 6\% körüli volt (Lekwa E Ysseldyke, 2010).

Egy másik vizsgálatban az 1999-ben a PsychINFO-n jegyzett 35878 empirikus tanulmányból véletlenszerűen kiválogatott 200 elemes mintán megvizsgálták, milyen arányban használják a különböző kutatási eljárásokat az egyes pszichológiai szakterületek (Bodner, 2006). Az 1. táblázatból láthatjuk, hogy a megfigyelést általában csak minden negyedik vagy ötödik kutató választja - bár a szakterülettől is nagyban függ, hogy mely módszereket preferálják. A fejlődéslélektani vizsgálatok közt szerepel a megfigyelés a legnagyobb arányban, ott a vizsgálatok egynegyede használ megfigyelést. 
A kisgyermeknevelő-gyermek interakciók megfigyelésével kapcsolatos kihívások

\begin{tabular}{|c|c|c|c|c|c|}
\hline & Alkalmazott $\Psi$ & 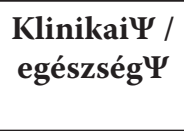 & Fejlődés $\Psi$ & 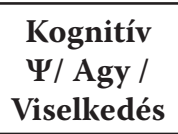 & 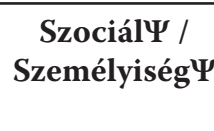 \\
\hline Önkitöltős kérdőív & $45 \%$ & $52 \%$ & $27 \%$ & $13 \%$ & $45 \%$ \\
\hline Interjú & $48 \%$ & $59 \%$ & $36 \%$ & $4 \%$ & $33 \%$ \\
\hline Megfigyelés & $19 \%$ & $6 \%$ & $27 \%$ & $10 \%$ & $11 \%$ \\
\hline $\begin{array}{l}\text { Viselkedésmérés } \\
\text { (pl. feladatteljesítés, } \\
\text { reakcióidő) }\end{array}$ & $3 \%$ & $0 \%$ & $45 \%$ & $58 \%$ & $23 \%$ \\
\hline Fiziológiás mérés & $3 \%$ & $13 \%$ & $9 \%$ & $50 \%$ & $19 \%$ \\
\hline
\end{tabular}

1. táblázat: A különböző pszichológiai tudományterületek által használt kutatási eljárások (Bodner, 2006. 267. o.)

A fent említett vizsgálatok (Lekwa $\mathcal{E}$ Ysseldyke, 2010; Bodner, 2006) is arra utalnak, hogy a megfigyelést inkább mellőzik a vizsgálatok, mivel a jó megfigyelés idő- és energiaigényes, azaz költséges kutatási eljárás.

Mindamellett fontos látnunk, hogy a kisgyermekek viselkedésének jellemzésére megbízhatóbbnak tünik a viselkedés közvetlen megfigyelése a gondozók kikérdezése helyett. A kisgyermeknevelés procedurális minőségének jellemzésére részletesebb és pontosabb adatokat szolgáltat az interakciók közvetlen megfigyelése, mint az interakcióban résztvevő felnőttek utólagos beszámolói.

Miért interakciók megfigyeléséről beszélünk? A 20. század pszichológiai kutatásait áttekintve (bővebben lásd Gyöngy, 2017), elmondható, hogy a nevelők szerepéről alkotott felfogásunk több szempontból fejlődött. Egyik fö elörelépésnek azt tekintjük, hogy az egyirányú, nevelőtől a gyermek irányába való hatásról való gondolkodást átvette a diádok egymásra hatásának vizsgálata, az empirikus vizsgálatok egyre inkább az interkaciók (azaz „viszonyválaszok”: verbális kommunikáció, non-verbális/ cselekvéses válaszok, társas megnyilvánulások) tanulmányozására tértek át (Maccoby, 1992). Az 1970-es évektől beszélhetünk interakciós kutatásokról, melyek a nevelő és a gyermek társas helyzetben lezajló, kölcsönös, egymáshoz viszonyított viselkedését vizsgálták. Ezeknek a vizsgálatoknak a hozománya, hogy már diádok egymásra hatását vizsgálják, nem egyes személyeket. Nem csupán a felnőtt gyermekre gyakorolt nevelöi eszközeiről (top-down folyamatról), hanem a gyermek sajátosságaihoz igazított hatásrendszerről beszéltek.
A nevelő és kisgyermek közti interakciók megfigyelése három célból történhet: terápiás helyzetben vagy a pedagógiai gyakorlat részeként, illetve tudományos érdeklődésből. Ezeket tekintjük át a következőkben.

\section{Interakciók megfigyelése terápiás célból}

Az interakciók klinikai helyzetben való megfigyelésére két Magyarországon is alkalmazott terápiás célú módszert, és egy külföldi megfigyelési szempontrendszert mutatunk be.

\subsection{Szülö-csecsemö konzultáció}

Az egyik terápiás eljárás a szülő-csecsemő konzultáció, mely Magyarországon a kétezres évek elején került be a szakmai köztudatba. 2005-ben indultak el az első továbbképzések, melyekre a kisgyermekekkel foglalkozó különböző szakemberek (gyermekorvos, védőnő, pszichológus, csecsemő- és kisgyermeknevelö) jelentkezhettek (Hédervári-Heller, 2008).

A szülő-csecsemő konzultáció pszichoanalitikus és kötődéselméleti gyökerü konzultáció, melynek központjában a baba-mama kapcsolat áll. Azokban az esetekben tud segítséget nyújtani, ahogy a szülö-csecsemő kapcsolat patológiásan fejlődik, valamilyen okból terheltté válik (Hámori, 2016). A tüneteket általában a csecsemő vagy kisgyermek viselkedésében látjuk: az együttműködés, a viselkedés szabályozása, valamint a táplálás és a megnyugtathatóság terén nehézségek lépnek fel. A konzultációhoz szükséges a kap- 
csolati nehézségek azonosítása, mely az interakciók megfigyelése révén lehetséges.

A konzulensek kiképzése során a megfigyelés oktatásához a Bick-féle csecsemőmegfigyelés elemeit használják (Hámori és Rajnik, 2018). A pszichoanalitikus Esther Bick a családok otthonaiban végzett megfigyelés fontosságára és létjogosultságára mutatott rá, amikor a csecsemőmegfigyelés technikáját kidolgozta. A családokban megnyilvánuló kapcsolatokat és ezek jellemzőit akarta tetten érni a heti rendszerességü megfigyelések révén. Utólag írt (retrospektív) jegyzeteket használt, melyek abban a tekintetben törekedtek objektivitásra, hogy a megfigyelő saját érzelmi válaszait figyelembe vették, illetve azt, hogy ezek az érzelmi válaszok mikor, hol és hogyan segítették a megfigyeltek megértését (Hollway, 2012). Ezeknek a megfigyeléseknek célja volt, hogy a megfigyelő minél függetlenebbül, minél kevésbé beavatkozóan tudjon megfigyelni, ugyanakkor tudatosítsa, hogy jelenléte és érzelmi involváltsága révén nagyon is részesévé válik a folyamatnak. A lejegyzett megfigyeléseknél törekedett arra, hogy az "objetkív” megfigyeléseket különválassza a benne keletkező benyomásoktól, érzésektől. Tehát ezeknek a megfigyeléseknek célja - a családban zajló események rögzítésén túl - a terapeuta szenzitivitásának fokozása is volt. Ezek a törekvések megjelennek a szülő-csecsemő konzulensek képzésében is, azzal a kiegészítéssel, hogy a szülö-csecsemő konzulensek képzésében már videófelvételeket is használnak (Hámori és Rajnik, 2018).

\subsection{Videótréning}

Egy másik terápiás eljárás a holland eredetủ videótréning, melynek során családi vagy tanár-diák interakciók videófelvételeinek felhasználásával nyújtanak segítséget a klienseknek. Magyarországon 1999-től elérhető a módszer. A videótréning során egy-egy specifikus készség célzott fejlesztésére van mód, hatásosságát kontrollcsoportos vizsgálatokkal igazolták (pl. Fukkink E Tavecchio, 2010).

Segítő Kamerának is hívják az eljárást, mivel a videófelvétel központi szerepet játszik benne. A rögzített felvétel a valós idejű megfigyelésnél több lehetőséget ad az aprólékos elemzésre, mivel többször megtekinthetők a részletek, ezáltal nagyító alá kerülnek az interakciók.

A segítő folyamat azzal kezdődik, hogy a kliens egy kérdést vagy megrendelést fogalmaz meg. Ezt követően a kliensről egy videófelvétel készül abban a természetes helyzetben, melyben a probléma jelentkezni szokott. Ezt a felvételt elemzi a videótréner. A felvételből kiválasztja azokat a részeket, melyekben a kliens interakciója sikeres volt, majd ezeket megmutatja neki, ezáltal megerősítve őt abban, hogy képes a jól működő kommunikációra (Sallai, 2011).

$\mathrm{Az}$ interakciók elemzése öt alapelv (Schepers E König, 2002; 2. táblázat) alapján történik, melyeket sikeres családi interakciókban azonosítottak be (a gyermek kezdeményezéseire való nyitottság, a válaszkészség, az interakciók pozitív légköre, a „sorra kerülés”, és az irányítás).

\begin{tabular}{|l|l|}
\hline Kapcsolati alapelv & Az alapelv megnyilvánulása a sikeres családi interakciókban \\
\hline $\begin{array}{l}\text { A gyermek kezdeményezéseire való } \\
\text { nyitottság }\end{array}$ & 1. A szülők követik a gyermek kezdeményezéseit \\
\hline Válaszkészség & $\begin{array}{l}\text { 2. A szülők megerősítik a gyermekeik kezdeményezéseit, elismerik } \\
\text { jelzéseiket azzal, hogy reagálnak rá }\end{array}$ \\
\hline Az interakciók pozitív légköre & $\begin{array}{l}\text { 3. A szülők pozitívan építik fel az interakciókat, a pozitív mintákat } \\
\text { verbális és non-verbális „igenekkel” megerősítik }\end{array}$ \\
\hline „Sorra-kerülés” & $\begin{array}{l}\text { 4. A szülők gondoskodnak arról, hogy a családtagok kölcsönös } \\
\text { váltakozó figyelemben részesüljenek }\end{array}$ \\
\hline Irányítás & 5. Általában a szülők vezetik /irányítják az interakciókat. \\
\hline
\end{tabular}

2. táblázat: A jól működő családok jellemzői a családi videotréning szerint (Schepers E König, 2002. 32-33. o.) 
A kisgyermeknevelő-gyermek interakciók megfigyelésével kapcsolatos kihívások

„A videotréningben a kinagyított interakciók leírására szolgáló mikroelemzés kódrendszere Trevarthen munkásságát alapul véve tartalmaz elfogadó és elutasító válaszokat, valamint figyeljük a kezdeményezéseket és azok fogadását. A kódrendszer minden kategóriájához rendelhetünk konkrét és a felvételeken is megfigyelhető viselkedés-elemeket. A tréning során általában az a célunk, hogy a rendszer tagjai között növeljük az elfogadó válaszok arányát, javítsuk azok minőségét, és növeljük a kezdeményezés-fogadás ciklusok számát és spontaneitását. A módszer lényegéhez tartozik, hogy a felvételek visszajelzése során csak ezeket a jó mintákat mutatjuk meg a kliensnek." (Gombás, 2018. 251. o.)

A videó a megfigyelésnek olyan szintű megbízhatóságát hozta magával, mely korábban csak sejtett összefüggések bizonyítását lehetővé tette. Például, a családi interakciós minták videóval történő rögzítése és mikro-elemzése révén lehetővé vált a transzgenerációs traumák átadásának tetten érése is az anya-csecsemő interakciójának mintázatában. Stupiggia egy olyan esetet említ, melyben a csecsemő fulladásos tüneteket mutatott. A megfigyelés révén derült ki, hogy az anyja az interakcióban olyan tempót diktált, mely mellett a természetesen jelen levő szünetek hiányoztak, ezáltal „levegőtlenség” alakult ki a kettejük kommunikációjában. Miután az anyának megtanították az interakció helyes tempóját, a csecsemő fulladásos tünetei elmúltak (Stupiggia, 2011).

\subsection{PICCOLO}

A klinikai felhasználású megfigyelési rendszerek közt még egy külföldi példáról mindenképp érdemes szólni. Védőnők, szociális munkások, családsegítők, fejlődéspszichológusok és egyéb klinikusok által használt mérőeszköz a PICCOLO, melyet szülő-gyermek interakciók megfigyeléséhez fejlesztettek. A PICCOLO a Parenting Interactions with Children: Checklist of Observations Linked to Outcomes rövidítése, melynek jelentése: „Szülö-gyermek interakciók: Fejlődési kimenethez kapcsolódó megfigyelések szempontlistája" (Roggman, Cook, Innocenti, Vonda, \& Christiansen, 2013). A PICCOLO-t arra fejlesztették, hogy családlá- togató szakemberek észrevegyék a pozitívumokat a szülők gyermekekhez való viszonyulásában, és támogathassák őket a kapcsolat javításában. A PICCOLO egy 10-47 hónapos korú gyermek és egyik (vagy mindkét) szülöje közt zajló interakció jellemzésére való (ha mindkét szülőt jellemezzük, értelemszerűen külön-külön jellemezzük a gyermekkel való kapcsolatukat). A PICCOLO szempontjait legkönnyebben a szülő és a gyermek játéka során tudjuk megfigyelni, 10 perc elegendő hozzá. A családlátogatás során a szakember tanúja a szülő és a gyermek közt zajló interakciónak, és egy ellenőrzőlista segítségével rögzíti, hogy látott-e pozitív elemeket a felnőtt gyermekére adott viszonyválaszaiban.

A PICCOLO eszköz (Roggman, Cook, Innocenti, Vonda, \& Christiansen, 2013; Roggman és mtsai, 2013; ill. Clarke, é.n.) négy szempontból vizsgálja a szülők és gyermekek közti interakciót (1. érzelmi viszonyulás, 2. válaszkészség, 3. bátorítás, 4. tanítás). Egy-egy szemponton belül hét jellemző megjelenését figyeljük 10 perc alatt. Az adott szempontok jelentkezését egy háromfokú skálán jelöljük: egyértelműen, alig vagy nem láttuk megjelenni a megfigyelés ideje alatt.

A megfigyelési szempontrendszer egyszerüsége miatt a családlátogatók általában egyetértenek abban, hogy látták-e az adott jelenséget vagy sem. A megfigyelés elsajátítása egy oktatófilm segítségével történik. Ismételt látogatások során a családokat támogatják a pozitív válaszokban, és az eszköz segítségével monitorozni tudják a fejlődést.

A szakemberré válás útján a PICCOLO szempontsora abban tud segítséget nyújtani, hogy felhívja a figyelmünket a szülö-gyermek interakciók fejlődésileg jelentős momentumaira. Ezeknek a jeleknek a felismerése minden olyan szakember számára hasznos, akik kisgyermekekkel és családjuk támogatásával foglalkoznak.

\section{Pedagógiai megfigyelés a kisgyermeknevelésben}

A kisgyermeknevelésben a megfigyelés célja, hogy minél jobban értsük a gyermek igé- 
nyét, viselkedését, hogy minél jobban tudjuk támogatni a fejlődését. Tesszük ezt azért, mert a bölcsődében gondozott-nevelt gyermekek nyelvi készségei, illetve önismerete még nem olyan fokú, hogy el tudnák mondani igényeiket, egyértelműen ki tudnák fejezni szükségleteiket, indítékaikat stb. Így az önkifejezés korlátolt volta és esetlegesen a nyelvi készségek teljes hiánya mellett kell tudnunk a gyermekek jelzéseit értelmezni, szükségleteikre válaszolni, kommunikálni velük. Ezen túl megfigyeléseink célja saját pedagógiai cselekedeteink hatásosságának monitorozása, illetve a gyermekek fejlődésének nyomon követése.

\section{1. Általános kívánalmak a pedagógiai megfigyeléssel kapcsolatban}

Ahhoz, hogy a gyermekek viselkedésének értelmezésére alkalmas legyen, a pedagógiai megfigyelést bizonyos szempontok szerint érdemes végezni.

\subsubsection{Objektív viselkedésleírás}

A megfigyelési jegyzőkönyv szövege következtetések nélküli, értelmezésre váró szöveg. Amikor az események zajlanak, elsősorban adatot gyüjtünk, az elemzést későbbre hagyjuk. A jegyzőkönyvírás közben olyan szavakkal írjuk le az eseményeket, melyek nem tartalmaznak értékelést vagy értelmezést, „... inkább a konkrét tényeket figyeljük meg, azonosítsuk és jegyezzük fel, ne pedig az általánosságokat, elvont fogalmakat, vagy hamarjában kialakult benyomásainkat." (SzántóFéder, 2017. 176. o.) Ez a törekvés ellentétben áll azzal a sokszor automatikusan alkalmazott tendenciával, hogy a mások viselkedése mögött meghúzódó okokra és mozgatórugókra próbálunk következtetni.

A megfigyelés tanulásakor érdemes videófelvételeken gyakorolni a készséget, hiszen így a bizonytalanságok a felvétel ismételt megtekintésekor tisztázhatók. Továbbá nagy segítség a videófelvétel megállíthatósága, mivel a kezdő megfigyelőknek általában nehézséget okoz a viselkedés szavakkal való megragadása, illetve a szándéktulajdonítás helyett („a csecsemő meg akarja szerezni a labdát”) a megfigyelhető viselkedés leírása („a csecsemő bal oldalán fekve bal kezét feje fölé emelve, középső ujjával a labda felé nyújtózkodik").

Mivel a gyermekmegfigyelések esetében gyakran olyan kisgyermekeket figyelünk meg, akiket nem tudunk kikérdezni szándékaikról, ezért az apró viselkedéses jegyekből tudunk csak következtetni belső indítékaikra. Ahhoz, hogy valós indítékaikra tudjunk következtetni, meg kell hagyni annak a lehetőségét, hogy tévedhetünk azonnali következtetéseinkkel. Ezeket a tévedéseket elkerülendő ragaszkodunk a viselkedés leírásához a megfigyelési jegyzőkönyv készítésekor.

\subsubsection{Részletgazdagság, konkrétumok emlitése}

Ha a szöveg minél nagyobb pontosságra és részletgazdagságra törekszik, akkor mások számára is elemezhető lesz. „[...] ez azok szempontjából is fontos, akikkel megfigyeléseinket szeretnénk megosztani. Így például mondhatom a kollégámnak: »ma reggel minden rendben zajlott Julikával«, vagy »jól viselkedett « - a kolléga biztosan örülni fog. De ha precízebben akarok fogalmazni, akkor ilyesmit is mondhatok: »Képzeld, mennyi mindent csinált Julika ma reggel, többször is próbálkozott, és amikor végül sikerült neki, nevetett!« vagy »Amikor kértem, hogy nyújtsa a kezét, rám mosolygott, és nagy örömmel teljesítette a kérésemet. « Ha így fogalmazok, a kollégám pontosan mega elé tudja képzelni a jelenetet - úgy fogja érezni, mintha ő maga is ott lett volna." (Szántó-Féder, 2017. 176. o.) A konkrétumok megnevezése és a részletgazdag leírás révén azok is el tudják képzelni a történéseket filmszerűen, akik esetleg nem voltak jelen (Tardos, 2018).

\subsubsection{Kontextus}

A megfigyelés kontextuális adatai is rögzítésre méltók: a megfigyelést végző személy kiléte, időpont, helyszín, kit figyel meg (maximum a gyermek keresztnevét írjuk le), hányan vannak jelen, mi történik épp a megfigyelés kezdetekor stb. 
A kisgyermeknevelő-gyermek interakciók megfigyelésével kapcsolatos kihívások

\subsubsection{Kérdésfeltevés}

A megfigyelés indítékát is érdemes rögzíteni a jegyzőkönyvben, azaz a kérdést, amire a megfigyelés révén választ remélünk. Ez a kérdés irányítja a figyelmünket a megfigyelés során. Így különbséget tudunk tenni a kérdésünk szempontjából lényeges és lényegtelen részletek közt.

Milyen kérdéseket szoktunk feltenni? A mindennapokban megfigyelhetjük a gyermekek érdeklődését, igényeit, ezáltal egyre szenzitívebb válaszokat tudunk adni igényeikre. Megfigyelést készítünk, amikor egy nevelési nehézség kapcsán a problémás viselkedés kiváltó tényezőit keressük. Gyakori, hogy ehhez a gyermeknél tapasztalt látványos viselkedéses tünet közvetlen előzményeit kell minél objektívabban rekonstruálni. Az „előzmény nélkülinek” címkézett problémás viselkedés (például látványos kétségbeesés, negatív indulatkitörések) kiváltó okai a szisztematikus megfigyelések révén beazonosíthatóvá válnak. Ehhez azonban szükséges elsősorban a pontos kérdésfeltevés, majd a gyermeki viselkedés szociális kontextusban való elfogulatlan megfigyelése, végül egy több szempontú elemzés, vagyis a megfigyeltek logikus áttekintése.

\subsection{A leggyakrabban használt megfigyelési jegyzökönyvek típusai a kisgyermeknevelésben}

A magyar kisgyermeknevelés leginkább narratív, azaz elbeszélő jellegű jegyzőkönyveket használ a viselkedés rögzítésére, melyekben verbálisan (írásban vagy szóban) adjuk vissza a történéseket. A jegyzőkönyveket megkülönböztetjük elkészítési időpontjuk és részletgazdagságuk tekintetében (ld. 3. táblázat).

\begin{tabular}{|l|l|l|l|}
\hline & Anekdotikus feljegyzések & Teljes jegyzőkönyv & Szelektív jegyzőkönyv \\
\hline Mikor készül? & Utólag & $\begin{array}{l}\text { Az eseményekkel egy } \\
\text { időben }\end{array}$ & $\begin{array}{l}\text { Az eseményekkel egy } \\
\text { időben }\end{array}$ \\
\hline Részletgazdagság & x Elfelejtett részletek & $\checkmark$ Teljességre törekszik & $\begin{array}{l}\times \text { Csak a megfigyelt } \\
\text { szempont }\end{array}$ \\
\hline
\end{tabular}

3. táblázat: Narratív jegyzőkönyvek jellemzői

\subsubsection{Anekdotikus feljegyzések}

Anekdotikus feljegyzéseket akkor készítünk, amikor nem nyílik lehetőségünk az események azonnali rögzítésére. Az események után visszaemlékezve írjuk le a történéseket, egy-egy gyermeki megnyilatkozás beleszövésével, ha ezekre emlékszünk. Az anekdotikus feljegyzés sokszor hasonlít egy rövid történetre, melynek van eleje, közepe, befejezése. A megfigyelési formák közül ez hasonlít a legjobban a köznapi visszaemlékezéseinkre, azonban a mindennapos történetmesélésektől annyiban különbözik, hogy értelmezést nem tartalmaz. Az interpretációkat a kívülről megfigyelhető eseményektől elválasztva, az elemzésben írjuk csak le. Az anekdotikus feljegyzések kiegészíthetnek fotókat, gyermeki alkotásokat is. Mivel visszaemlékezésből történik az események leírása, ezért sokszor csak megközelítőleg tudjuk megmondani, hogy mikor történtek a megfigyeltek (dátum, napszak). Ez a megfigyelési forma teszi lehetővé azoknak az eseményeknek rögzítését, melyben a megfigyelö maga is részt vett. (Herr, 2008; Bruce, Louis \& McCall, 2014)

\subsubsection{Teljes jegyzőkönyv}

A teljes jegyzőkönyv adott időszak alatt a történések teljes körű rögzítésére törekszik. Adott időtartam alatt figyelve a gyermek(ek) és felnőttek tevékenységét, írásban folyamatosan rögzítjük a cselekménysort. A megfigyelés végzése alatt passzív módon a háttérbe igyekszünk olvadni. Érdemes egy olyan helyet választanunk, mely közel van a megfigyelt cselekményhez, ahol halljuk a beszélgetést, de próbáljuk a távolságot tartani annyira, hogy a gyermekeket ne feszélyezzük. Taná- 
csos pár percig várni az írás elkezdésével, hogy a gyermekek megszokhassák jelenlétünket. Miközben kívülállásunkkal célunk a történések tőlünk független rögzítése, természetesen számolunk azzal, hogy a gyermekekre valamilyen szinten hatással lesz jelenlétünk. A történésekkel egyidejű jegyzetelés csak korlátolt időtartamig fenntartható, mivel az események általában gyorsabban zajlanak, mint ahogy képesek vagyunk szavakkal megfogalmazni és leírni őket. Ezért, amennyiben nincs lehetőségünk videófelvétel készítésére és az arról való utólagos jegyzőkönyvírásra, akkor érdemes a verbális megnyilatkozásokat szó szerint leírni, a non-verbális jegyekre pedig rövidítéseket alkalmazni, a megfigyelés végeztével pedig ezek alapján kiegészíteni, letisztázni a jegyzőkönyvet (Tassoni, Beith, Eldridge E Gough, 2002; Bruce, Louis E McCall, 2014; Falus, 2014).

\subsubsection{Szelektív jegyzőkönyv}

A szelektív jegyzőkönyv készítésekor egy szempont előfordulását keressük. Tehát a kérdés az, hogy egy hosszabb (akár 1,5 órás) megfigyelési időszak alatt hányszor és hogyan fordul elö egy adott dolog (optimális esetben rögzítjük az előfordulás időpontját és hosszát is). A jegyzőkönyvvezetéshez azonnali kiértékelés szükséges a helyzetről, hogy a jelenség a megfigyelési szempont kritériumába illik-e. Azaz, ha például a nevelő érzelmi biztonságot teremtő tevékenységeit figyeljük meg, akkor a nevelőnek mindazon viselkedésformáit rögzítjük, melynek érzelemszabályzó funkciója van a gyermekek számára, de más viselkedéseit nem írjuk le (Tassoni, Beith, Eldridge E Gough, 2002).

\subsection{A megfigyelés elemzése}

A pedagógiai megfigyelések elemzésekor általában nem használunk kódrendszert, az elemzési szempontokat a kérdésfeltevés irányítja. A szakmai vélemény megfogalmazásakor a jegyzőkönyvből azokra a történésekre érdemes hivatkozni, melyek a kérdésfeltevéshez kapcsolódnak, ezáltal lesznek visszakövethetők, és nem légből kapottak a kö- vetkeztetések. Mivel általában egyetlen eset megfigyeléséről van szó (single case design) vagy esetleg ugyanannak a gyermeknek a visszatérő megfigyeléséről, ezért a megfigyelés elemzése túlnyomórészt kvalitatív jellegű.

\section{Interakciók megfigyelése tudományos érdeklődésből}

Amikor a megfigyelést empirikus adatgyüjtési célra használjuk, tipikusan egynél több eset megfigyelését tervezzük olyan szempontok szerint, melyeket objektíven és megbízhatóan kell tudnunk alkalmazni.

\subsection{Az interakció rögzitése kutatási célra}

Az interakciót rögzítenünk kell valamilyen módon, hogy az elemzésre alkalmas adatokat szerezzünk. Ez történhet a megfigyeléssel egy időben vagy utólag hang- vagy videófelvétel segítségével.

A kezdeti vizsgálatokban az interakciókat valós időben gyorsírással vagy hangfelvétellel rögzítették. Például Milton, Kagan és Levine (1971) az 1970-es évek elején a következőképp figyelte meg a felnőttnek azokat az interakciós viselkedéseit, melyek célja, hogy a gyermekek viselkedését szabályozza. Anyák és 27 hónapos kisgyermekeik otthon zajló interakcióit úgy rögzítették, hogy egy megfigyelő kézzel írt feljegyzéseket készített az interakciókról két alkalommal, két és fél órás megfigyelések alatt. Az összesen ötórányi megfigyelésnek csak töredékét rögzítette a megfigyelő. Akkor kezdte el leírni az interakciót, ha a gyermek kért valamit az anyjától vagy (az anya szemében) normaszegő viselkedést követett el; illetve, ha az anya megrótta, figyelmeztette vagy utasította a gyermeket, hogy valamit tegyen, vagy ne tegyen meg. A későbbiekben ezeket a kézzel írt feljegyzéseket kódolták a kutatók (Milton, Kagan \& Levine, 1971).

Az 1980-as évektől a technika fejlődése lehetővé tette a mikroanalitikus vizsgálatok végzését is, lassított és visszapörgetett videófelvételek segítségével. Kuczynski és munkatársai laboratóriumban berendezett apartmanban figyelték meg anyák és tipegő 
A kisgyermeknevelő-gyermek interakciók megfigyelésével kapcsolatos kihívások

gyermekeik természetesen előforduló interakcióit. Ételkészítés, étkezés, az azt követő rendrakás, játék stb. közben és az eközben előforduló irányítási epizódokat vizsgálták (Kuczynski, Kochanska, Radke-Yarrow E Girnius-Brown, 1987).

Mára az anyák és tipegő gyermekük interakcióinak elemzése kiterjedt szakirodalommal rendelkezik; az interakcióról tipikusan videófelvétel készül (pl. Parpal \& Maccoby, 1985; Crockenberg \& Litman, 1990; Kochanska E Aksan, 1995; Laible E Thompson, 2002).

\subsection{Videófelvételek készítésének technikai buktatói}

$\mathrm{Az}$ interakciók elemzésére alkalmas videófelvételek készítésének számos buktatója van. Ezek megelőzéséhez néhány technikai akadályt kell leküzdeni. Mára már alapelv a digitális képrögzítés, így lesz alkalmas a felvétel a számítógépen való tárolásra, (vágásra), megtekintésre, elemzésre. A képminőség jó legyen (HD, optimális tömörítés mellett) és az operatőr úgy helyezkedjen a teremben, hogy a felvételen látszódjanak a felnőtt(ek) és a gyermekek közt zajló interakciók részletei (pl. arckifejezések, gesztusok stb.). A teret lássa be a kamera (legyen rászerelhető széleslátószögű vagy halszem objektív), vagy több kamerát alkalmazzunk különböző irányokból.

A megfelelő képminőséget eredményező videokamera beszerzésén túl az interakciók rögzítésének, különösképpen a többszereplős, például gyermekcsoportban zajló interakciók felvételének másik nagy kihívása a megfelelő minőségű hangrögzítés. Ennek hiányában a meglehetősen hangos környezetben halk hangon szólók verbális interakciói elemezhetetlenné válnak, és a non-verbális kontextus is értelmezhetetlen. A kamerába épített mikrofon nem képes olyan hangfelvételre, melyből a távolabb állók beszéde kivehető lenne, mivel a csoportszoba egyéb zajai elnyomják a felnőtt egy-egy gyermekhez szólásának hangját. A kamerába épített mikrofon amúgy is torzító képet ad a csoportszoba hangzó világáról, mivel minden egyes zajt ugyanolyan erősséggel vesz fel, az emberi fül által való szűrést és emberi beszédhang-preferenciát képtelen kivitelezni. Ennek technikai megoldása a vezeték nélküli, felnőttre erősített mikroport lehet.

A viselkedés megfigyelésével kapcsolatos nehézség, hogy a megfigyelő - videófelvétel készítése esetén az operatőr - jelenléte a gyermekek viselkedését befolyásolhatja: félénkség vagy épp ellenkezőleg magamutogatás jelentkezhet a játéktevékenység helyett.

$\mathrm{Az}$ operatőr személyének a gyermekek viselkedésére gyakorolt hatása kétféleképp küszöbölhető ki. Az egyik megoldás az, ha csak a kamera van a csoportszobában. Ezzel az elrendezéssel több gond lehet. A csoportszobában állandóan mozgó felnőttek és gyermekek kimehetnek a kamera látószögéből, arcukkal elfordulhatnak a kamerától. Azok az elrendezések, melyek nem alkalmaznak csoporton belüli operatőrt (Bayer, Whaley \& May, 1995; Kurki, Järvenoja, Järvelä \& Mykkänen, 2016), minimum három különböző ponton elhelyezett távirányítású kamerát használnak, és a felvételt egy kontrollszobából felügyeli és irányítja az operatőr. Ha ennek az elrendezésnek az anyagi költségei túlmutatnak kutatásunk lehetőségein, másik stratégiát kell választanunk.

A másik megoldás a gyermekek kamerához és az operatőr jelenlétéhez szoktatása. Ennek is két módja lehetséges. Egyrészt, a tényleges felvételt megelőző napon próbafelvétel készíthetünk, bár nem jár annyi előnnyel (a gyermekek viselkedése tekintetében), mint amennyi fáradság. Mivel a kisgyermekeknél gyakoriak a hiányzások, ezért előfordulhat, hogy a felvétel napján nem pont azok a gyermekek vannak jelen, mint a próbafelvételkor. Érdemesebb helyette a másik módot választani: a felnőtt résztvevőknek egy szóbeli tájékoztatón a felszerelést kézbe adva bemutatni (őket is szoktatva a felszereléshez), megkérni őket, hogy a gyermekekkel beszélgessenek arról, hogy „egy néni jön majd, hogy megnézze, hogyan játszanak”. A felvétel napján a felvétel kezdete előtt legalább 15 perccel érdemes a csoportszobába belépni. Elsősorban a felnőt- 
tel beszélni és a felszerelést előszedni a táskából. Ha egy gyermek megszólítja az operatőrt, barátságosan, de csak röviden válaszolni neki, nem megfeledkezve arról, hogy a cél az, hogy a gyermekek az operatőr jelenlétét megszokják, de ne akarjanak vele kapcsolatba kerülni.

Hogyan rögzíthető egy csoportszobán belül az összes történés? Példaként vegyük kutatásunkat (Gyöngy, 2017), melyben bölcsődés gyermekek és kisgyermeknevelőik interakcióját rögzítettük. A bölcsődei csoportszobák térileg tagoltak, a térelválasztók, mint például a polc vagy a virágtartó, többé-kevésbé átláthatóak. A gyermekek szabad játék során a szoba bármely pontján tartózkodhatnak, maguk döntik el, hogy a kisgyermeknevelő közelségében, vagy a felnőttől távol helyezkednek el. Amennyiben a megfigyelés során célunk az összes gyermek tevékenységének rögzítésre, akkor nem elegendő egyetlen kamerával a kisgyermeknevelőről és a környezetében elhelyezkedő gyermekekről készíteni felvételt, hanem szükség lesz egy második kamerára is, mely állványra rögzítve, halszemoptikával ellátva a csoportszoba történéseit veszi. Így két szögből készülhet ugyanarról a történésről felvétel (1. ábra).

Kérdés, hogy az így nyert két videofelvételt hogyan érdemes használni az elemzéskor. Egy lehetséges megoldás, hogy a két felvételt

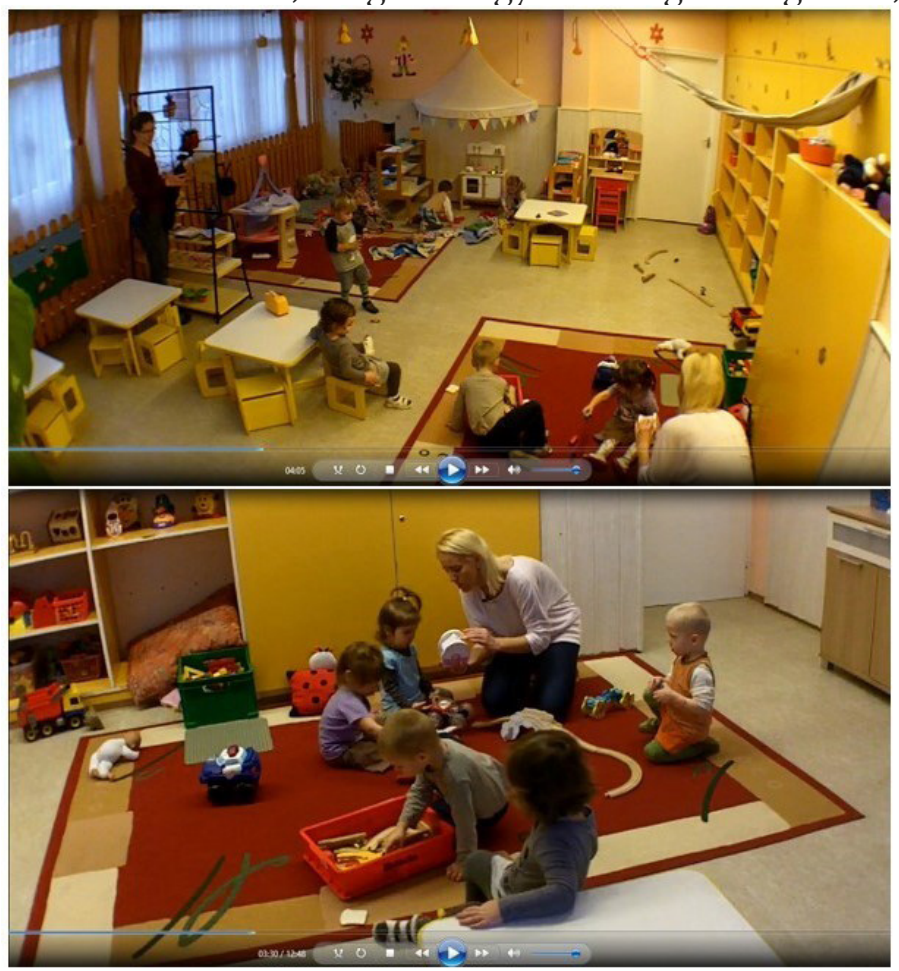

1. ábra: A bölcsődei csoportszobában használt két videokamera képe

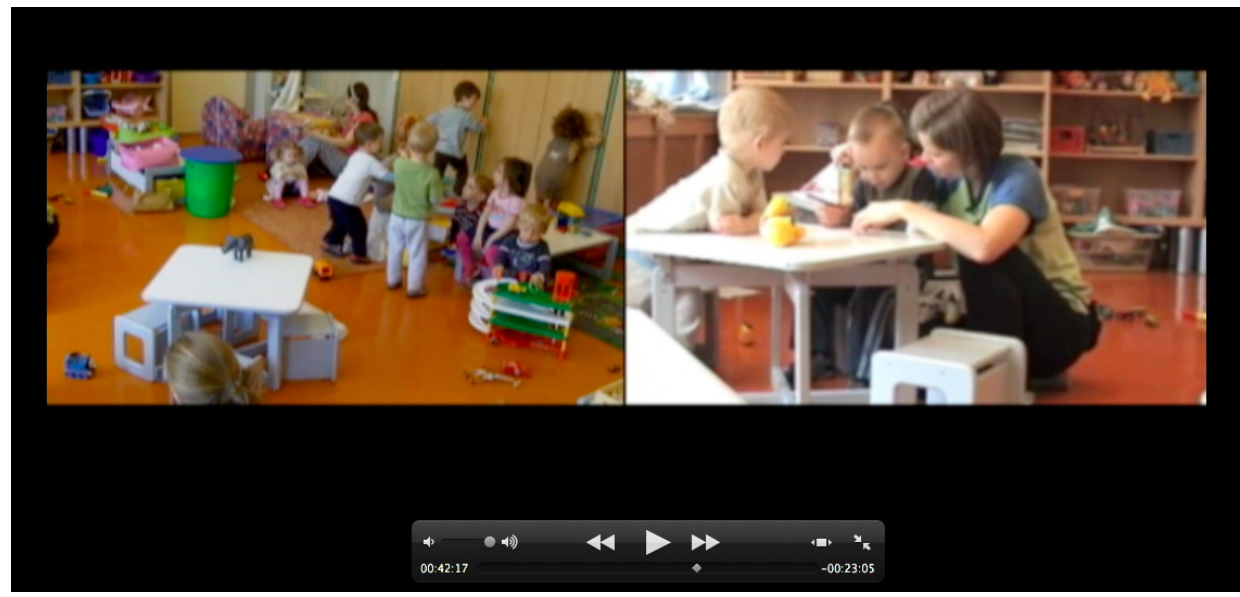

2. ábra: A videófelvételek osztott képernyős elrendezése 
A kisgyermeknevelő-gyermek interakciók megfigyelésével kapcsolatos kihívások

osztott képernyős módon egymás mellé helyezzük egy videó szerkesztő programmal (2. ábra).

Az osztott képernyős elrendezésről tudni kell, hogy a két független kamerával készülő felvételt össze kell szerkeszteni. Erre lehetőséget ad a többcsatornás videórögzítés (felszerelésigénnyel kell számolni), vagy utólag a videoszerkesztő programok kép a képben üzemmódja (időigényes).

Továbbá, a két különböző időpontban elindított kamera felvételében kell találni egy referenciapontot, amely alapján a két felvétel időben egymással átfedésbe kerül (ehhez szokás használni a csapót, vagy legalább tapsolást). Ha a két kamera különböző minőségben vagy formátumban rögzíti a felvételt, csak a rosszabb minőségű kép felbontásában menthető az összevágott videó. Az osztott képernyő miatt kisebb lesz a felvétel, hiszen egy képernyőn két videó játszódik egymás mellett Végül zavaró nézni a kétféle különböző mozgást a két képen, visszanézéskor a kódoló önkéntelenül is csak az egyik felvételt nézi.

Ezek miatt, bár csábítónak tünik az osztott képernyős videó használata, egyszerűbb a következő elv használata. Az elemzés alapjául azt a felvételt használjuk (tipikusan az operatőr által kezelt kézi kamera felvételét), melyen közelebbről látszik az interakció, és a halszemoptikával készített másodfelvételt akkor vesszük elő, ha az első számú felvételen nem látható egy történés.

\subsection{Videóra rögzített interakció elemzése - „offline” kódolás}

Ha az interakciót videóra rögzítjük és aztán kódoljuk, ezzel összességében időigényesebbé válik a kódolás, azonban számos előnye van a valós időben végzett megfigyeléssel szemben. Ilyenkor rövidebb időtartamú megfigyelés is elegendő. A kódrendszer kidolgozása a videófelvétel elkészítése után is lehetséges. A kódolás megbízhatósága újrakódolással ellenőrizhető. A megbízhatósági kódoláshoz nem kell, hogy egyidejűleg jelen legyen több kódoló. Később további videofelvételekkel bővíthető az adatbázis, újabb szempontok szerint elemezhető lehet a felvétel (Martin \& Bateson, 2007).

\subsection{Mások által kialakított kódrendszerek használata}

Amennyiben ismerünk kutatási kérdésünknek megfelelő kódrendszert, akkor érdemes ezt használni.

Ezekkel a kódrendszerekkel kapcsolatos alapvető kérdés, hogy a kódolást milyen felbontású elemzéssel végzik. A kódolás szintje lehet makro- vagy mikroszintü elemzés.

\subsubsection{Globális becslöskálák, avagy makroszintü elemzés}

Számos olyan kódrendszer létezik, mely globális becslőskálákon (rating scale) jellemzi a viselkedést. Ekkor a megfigyelt személyt vagy viselkedést a megfigyelés időtartama alatt adott szempont szerint egy pontszámmal jellemezzük egy ordinális skálán (példák a 4. táblázatban).

\begin{tabular}{|l|l|}
\hline \multicolumn{1}{|c|}{ Szerző } & \multicolumn{1}{|c|}{ A globális becslőskála elnevezése } \\
\hline Thomason \& La Paro, 2009 & CLASS-toddler (Classroom Assessment Scoring System) \\
\hline Dowling, Smith Slep, E O'Leary, 2009 & proaktív (preemptive) nevelöi viselkedés \\
\hline $\begin{array}{l}\text { Feldman, 2012; [franciául: Viaux-Savelon és mtsai, } \\
\text { 2014] }\end{array}$ & CIB: Coding Interactive Behavior \\
\hline $\begin{array}{l}\text { Helmerhorst, Riksen-Walraven, Vermeer, Fukkink \& } \\
\text { Tavecchio, 2014 }\end{array}$ & Caregiver Interaction Profile Scales \\
\hline
\end{tabular}

4. táblázat: Példák a nevelő-gyermek interakciók kódolására alkalmas globális becslőskálákra 
Egy adott konstruktum megfigyelése történhet különböző dimenziókon, melyeket külön-külön osztályzunk. Például, a CLASSkódrendszer tipegócsoportra alkalmazott verziójában (La Paro, Hamre E Pianta, 2012) a nevelö-gyermek interakciók jellemzése két területen belül nyolc dimenzión történik. A két fö terület az (A) érzelmi és viselkedéses támogatás, illetve a (B) az elkötelezettség a tanulás támogatásában. Ezeken belül a dimenziók: (A1., A2.) az érzelmi klíma (ezen belül megkülönböztetnek pozitív és negatív klímát), (A3.) a nevelői szenzitivitás, (A4.) a gyermek szempontjának figyelembe vétele, (A5.) viselkedésirányítás, illetve (B6.) a tanulás és fejlődés támogatása, (B7.) a visszajelzések minősége és (B8.) a nyelvi minta adása. A dimenziókon belül alskálák segítik az interakció jellemzését, például az (A5.) viselkedésirányítás főkategórián belül három alskála található: 5.1. nevelői proaktivitás, 5.2. pozitív viselkedésformák támogatása, illetve 5.3. a gyermekeknél jelentkező problémás viselkedések, melyeket a megfigyelők 1 és 7 közt pontoznak (5. táblázat).

\begin{tabular}{|c|c|c|c|}
\hline & \multicolumn{3}{|c|}{ A5 viselkedésirányítás } \\
\hline & Alacsony $(1,2)$ & Közepes $(3,4,5)$ & Magas $(6,7)$ \\
\hline $\begin{array}{l}\text { 5.1. nevelői proaktivitás } \\
\text { - } \quad \text { a gyermekek } \\
\text { viselkedésének aktív } \\
\text { figyelemmel követése } \\
\text { - } \quad \text { egyértelmű elvárások } \\
\text { kommunikálása } \\
\text { - } \quad \text { a gyermekek tisztában } \\
\text { vannak az elvárásokkal }\end{array}$ & $\begin{array}{l}\text { A nevelő nincs tudatában } \\
\text { a csoportszobájában levő } \\
\text { gyermekek viselkedésének. } \\
\text { A nevelő a szabályokat és } \\
\text { elvárásait nem tisztázza a } \\
\text { gyermekek számára, és a } \\
\text { gyermekek is úgy tűnnek, } \\
\text { mint akik nincsenek } \\
\text { tisztában a csoportszobai } \\
\text { viselkedéses szabályokkal és } \\
\text { elvárásokkal. }\end{array}$ & $\begin{array}{l}\text { A nevelö következetlenül } \\
\text { követi a gyermekek } \\
\text { viselkedését. Néha elmondja } \\
\text { a szabályokat és elvárásokat, } \\
\text { és/vagy a gyermekek } \\
\text { viselkednek úgy, mint akik } \\
\text { némileg ismerik ezeket a } \\
\text { szabályokat és elvárásokat. }\end{array}$ & $\begin{array}{l}\text { A nevelő következetesen } \\
\text { és aktívan monitorozza a } \\
\text { gyermekek viselkedését. } \\
\text { Esetleg el is mondja } \\
\text { az elvárásait, és vagy a } \\
\text { gyermekek úgy viselkednek, } \\
\text { mint akik tisztában vannak } \\
\text { a csoportszobai viselkedéses } \\
\text { szabályokkal és elvárásokkal. }\end{array}$ \\
\hline $\begin{array}{l}\text { 5.2. pozitív viselkedésformák } \\
\text { támogatása } \\
\text { - } \quad \text { pozitív viselkedések } \\
\text { megerősítése } \\
\text { - } \quad \text { hatékony elterelés } \\
\text { - } \quad \text { az elterelések, illetve a } \\
\text { kérések specifikusak } \\
\text { - } \quad \text { az elvárt viselkedés } \\
\text { pozitív megfogalmazása }\end{array}$ & $\begin{array}{l}\text { A nevelő elmulasztja } \\
\text { a gyermekek pozitív } \\
\text { viselkedéseinek támogatását. } \\
\text { Az elterelésre vonatkozó } \\
\text { kísérletei hatástalanok vagy } \\
\text { elhúzódóak, ismételtek, } \\
\text { illetve következetlenek. } \\
\text { Utasításai, megerősítései } \\
\text { vagy átirányításai általánosak } \\
\text { vagy a tiltott viselkedésről } \\
\text { szólnak a kívánatos } \\
\text { viselkedés helyett. }\end{array}$ & $\begin{array}{l}\text { A pozitív viselkedések } \\
\text { támogatása következetlen } \\
\text { a nevelő részéről. Néha } \\
\text { hatékony a nemkívánatos } \\
\text { viselkedés eltérítése, máskor } \\
\text { sikertelen. A nevelő keverten } \\
\text { alkalmazza utasításaiban } \\
\text { a pozitív felszólításait (mit } \\
\text { tegyenek a gyermekek) és a } \\
\text { tiltásokat („Nem!” vagy „Ne } \\
\text { tedd ezt, ne tedd azt!”). }\end{array}$ & $\begin{array}{l}\text { A nevelő következetesen } \\
\text { használ hatékony stratégiát } \\
\text { a gyermekek pozitív viselke- } \\
\text { désének támogatására. Az } \\
\text { elvárásoknak megfelelően } \\
\text { viselkedő gyermekek pozitív } \\
\text { megerősítést kapnak, a prob- } \\
\text { lémás viselkedést csökkenti } \\
\text { hatékony elterelés révén. A } \\
\text { nevelő konzekvensen a kívá- } \\
\text { natos viselkedést kommuni- } \\
\text { kálja a gyermekek felé, nem } \\
\text { a tiltottat. }\end{array}$ \\
\hline $\begin{array}{l}\text { 5.3. a gyermekeknél } \\
\text { jelentkezó problémás } \\
\text { viselkedések } \\
\text { - minimális császkálás } \\
\text { - minimális várakozás } \\
\text { - a bomlasztó és } \\
\text { potenciálisan veszélyes } \\
\text { viselkedések hiánya }\end{array}$ & $\begin{array}{l}\text { A gyermekek az idő jelentős } \\
\text { részében várakoznak vagy } \\
\text { bóklásznak. Elképzelhető, } \\
\text { hogy hosszabb időszakokon } \\
\text { keresztül diszruptív vagy } \\
\text { problémás a gyermekek } \\
\text { viselkedése. }\end{array}$ & $\begin{array}{l}\text { A gyermekek tevékeny- } \\
\text { kednek, vagy valamilyen } \\
\text { feladatot végeznek bizonyos } \\
\text { időszakokban, máskor } \\
\text { azonban várakoznak vagy a } \\
\text { csoportszobában járkálnak. } \\
\text { Rövid ideig elképzelhető } \\
\text { diszruptív vagy problémás } \\
\text { viselkedés. }\end{array}$ & $\begin{array}{l}\text { A gyermekek folyamatosan } \\
\text { tevékenykednek. Kevés } \\
\text { esetben fordul elő diszruptív } \\
\text { vagy problémás viselkedés, } \\
\text { ha egyáltalán előfordul. }\end{array}$ \\
\hline
\end{tabular}

5. táblázat: A CLASS-toddler Behavior Guidance dimenziójának áttekintése (ford. Gy. K.) (La Paro, Hamre \& Pianta, 2012: Dimension Overview) 
A kisgyermeknevelő-gyermek interakciók megfigyelésével kapcsolatos kihívások

Ezek használatával kapcsolatban tudnunk kell, hogy a publikációkban többnyire csak a skálák nevei szerepelnek. A kódrendszer pontos értelmét és használatának módját meg kell tanulnunk, mely gyakran csak fizetős kurzus keretében valósítható meg (például a CIB és a CLASS-toddler esetében), és csak sikeres kódolói megbízhatósági vizsga után használható az eljárás.

\subsubsection{Mikroszintü elemzés}

A mikroszintü elemzés azt jelenti, hogy a viselkedés elemi egységeit azonosítjuk, és ezeknek előfordulási gyakoriságait rögzítjük a megfigyelés során. Akkor szoktuk a viselkedésnek ilyen finom elemzését választani, ha azt szeretnénk tudni, hogy egy adott viselkedés milyen elemekből áll vagy egy hatásmechanizmus pontosan hogyan valósul meg.

Ezek a vizsgálatok munkaigényesebbek a makroszintű elemzésnél, emiatt általában alacsony elemszámot használnak. Vegyük példaképp ismét a felnőttnek azokat a viselkedésformáit, melyekkel kisgyermekek viselkedését szabályozzák. A kisgyermeknevelési kontextusban végzett, finomelemzést használó a viselkedésszabályozásról szóló vizsgálatok összefoglalását lásd a 6. táblázatban (B - bölcsődéskorú gyermekekkel, Ó - óvodáskorú gyermekekkel; KGYN - kisgyermeknevelö, GY - gyermek).

\begin{tabular}{|c|c|c|c|c|}
\hline Vizsgálat & Vizsgált kérdés & Gyermeki kimenet & B/Ó & Elemszám \\
\hline $\begin{array}{l}\text { Tardos, Dehelán és } \\
\text { Szeredi, } 1977\end{array}$ & $\begin{array}{l}\text { A Lóczy úti csecsemőotthon } \\
\text { óvodaházában a } \\
\text { kisgyermeknevelő erőszakmentes } \\
\text { irányításának elemzése }\end{array}$ & - & B & $\begin{array}{l}\text { KGYN: } 1 \\
\text { GY: nem } \\
\text { ismert, } \\
\text { egyszerre 3-4 } \\
\text { GY }\end{array}$ \\
\hline $\begin{array}{l}\text { Bayer, Whaley E } \\
\text { May, } 1995\end{array}$ & $\begin{array}{l}\text { A kgyn milyen viselkedéses } \\
\text { stratégiát alkalmaz tipegők } \\
\text { kortárskonfliktusai esetén? }\end{array}$ & $\begin{array}{l}\text { Azonnali gyermeki reakció a } \\
\text { viselkedésszabályozásra }\end{array}$ & B & $\begin{array}{l}\text { KGYN: } 12 \\
\text { GY: } 14\end{array}$ \\
\hline Kontos, 1999 & $\begin{array}{l}\text { A kgyn szabad játék során mit } \\
\text { tesz? }\end{array}$ & - & Ó & $\begin{array}{l}\text { KGYN: } 40 \\
\text { GY: nem } \\
\text { ismert, } 22 \\
\text { csoport }\end{array}$ \\
\hline $\begin{array}{l}\text { Wachs, Gurkas E } \\
\text { Kontos, } 2004\end{array}$ & $\begin{array}{l}\text { A gyermek engedelmességét } \\
\text { hogyan befolyásolja a kgyn-i } \\
\text { kontroll erőssége, a gy } \\
\text { temperamentuma, a környezeti } \\
\text { káosz, és a minőség? }\end{array}$ & $\begin{array}{l}\text { Azonnali gyermeki reakció a } \\
\text { viselkedésszabályozásra }\end{array}$ & Ó & $\begin{array}{l}\text { KGYN: nem } \\
\text { ismert, } 23 \\
\text { csoport } \\
\text { GY: } 86\end{array}$ \\
\hline $\begin{array}{l}\text { Williams, } \\
\text { Mastergeorge E } \\
\text { Ontai, } 2010\end{array}$ & $\begin{array}{l}\text { A kgyn milyen viselkedésekkel } \\
\text { támogatja a gyermekek társas } \\
\text { kapcsolatait? }\end{array}$ & $\begin{array}{l}\text { A gyermekek társas készségei } \\
6 \text { hónappal később }\end{array}$ & B & $\begin{array}{l}\text { KGYN: } 11 \\
\text { GY: } 36\end{array}$ \\
\hline $\begin{array}{l}\text { Degol E Bachman, } \\
2015\end{array}$ & $\begin{array}{l}\text { Alacsony SES-ű családok } \\
\text { gyermekeinek óvodáiban a } \\
\text { viselkedésszabályozással töltött } \\
\text { idő }\end{array}$ & $\begin{array}{l}\text { A gyermekek önszabályozása } \\
\text { a nevelési év végén }\end{array}$ & Ó & $\begin{array}{l}\text { KGYN: nem } \\
\text { ismert, } 29 \\
\text { csoport } \\
\text { GY: } 216\end{array}$ \\
\hline $\begin{array}{l}\text { Majorano, Corsano } \\
\text { E Triffoni, } 2015\end{array}$ & $\begin{array}{l}\text { Gyermekek közti konfliktusok } \\
\text { kezelésének mikéntje a kgyn } \\
\text { részéről, kgyn kommunikációs } \\
\text { stílusának leírása }\end{array}$ & A konfliktus kimenetele & B & $\begin{array}{l}\text { KGYN: } 16 \\
\text { GY: } 99\end{array}$ \\
\hline $\begin{array}{l}\text { Kurki, Järvenoja, } \\
\text { Järvelä \& Mykkänen, } \\
2016\end{array}$ & $\begin{array}{l}\text { Szocio-emocionálisan kihívást } \\
\text { jelentő helyzetekben a kgyn } \\
\text { hogyan szabályozza a gyermekek } \\
\text { érzelmeit, viselkedését, és utólag } \\
\text { hogyan értelmezi? }\end{array}$ & - & Ó & $\begin{array}{l}\text { KGYN: } 8 \\
\text { GY: } 30\end{array}$ \\
\hline
\end{tabular}

6. táblázat: Kisgyermeknevelési kontextusban végzett finomelemzéses interakciós vizsgálatok, melyekben szerepel a gyermekek viselkedését kívülről szabályzó felnőtt magatartás 
Bayer, Whaley és May (1995) vizsgálata jól példázza, milyen kérdések megválaszolására alkalmas a mikroszintű elemzés. Azt vizsgálták, hogy a kisgyermeknevelők milyen stratégiával indítják a viselkedésszabályozást, amikor a tipegők konfliktusaiba a beavatkoznak, s ennek milyen hatása van a gyermekek közti konfliktus megoldására. 135 konfliktushelyzet elemzésével arra jutottak, hogy alapvetően három beavatkozási típus volt tetten érhető a megfigyelt konfliktusok során. A leggyakrabban alkalmazott stratégia a gyermek verbális hívása volt, figyelmének megszerzése (CALL stratégia). Ahhoz, hogy a gyermek egy konfliktushelyzetben a vitát feladva a kisgyermeknevelőre tudjon figyelni, le kell állítania a konfliktusban való részvételt, és a figyelmét áttenni a konfliktusról a kisgyermeknevelőre. Ezt a vizsgálatban résztvevő bölcsődéskorú gyermekek általában nem voltak képesek megtenni, a konfliktusban való részvételt folytatták. Ha folytatódott a hívás után a konfliktus, akkor az ezt követő legvalószínűbb kisgyermeknevelői beavatkozási forma a viselkedés fizikai leállítása (STOP) volt (Bayer, Whaley \& May, 1995).

A második leggyakrabban alkalmazott indító beavatkozási forma rögtön a viselkedés fizikai leállítása (STOP) volt. Amennyiben a beavatkozás során a kisgyermeknevelő bármikor fizikai leállítást alkalmazott, utána a leginkább szabályállítással folytatta a beavatkozást, azaz a gyermekekkel ismertette az elvárt viselkedést, melyhez esetenként indoklást füzött. A fizikai leállítás, szabályok ismertetése, az elvárt viselkedés megmondása és az indoklás addig ismétlődött, míg a gyermek együtt nem működött a felnőttel (Bayer, Whaley \& May, 1995).

A fenti esetekben a gyermekek nem maguk jutottak el a konfliktus feloldásához, hanem a kisgyermeknevelő irányításának engedelmeskedtek. A konfliktushelyzetek 10\%-ában a fentihez képest másként követték egymást az események. Amennyiben a kisgyermeknevelő a beavatkozást olyan kérdéssel indította, mely a gyermekek szempontjait akarta feltárni (és nem kérdésbe burkolt szemrehányás volt), akkor válaszként a gyermek elmondta neki, hogy mit akar. A szándék verbalizálását a kisgyermeknevelő állványozó viselkedése, a tárgyalást segítő tanács („Mondd meg neki, hogy...”) vagy pozitív megerősítés („köszönöm...") követte, ennek révén a tipegők az esetek felében képesek voltak megegyezésre jutni egymás közt (Bayer, Whaley E May, 1995).

Összefoglalva Bayer, Whaley és May eredményeit, azt látjuk, hogy a kisgyermeknevelők a gyermeki konfliktusok esetén a beavatkozást szükségesnek találják, céljuk a konfliktusok minimalizálása, csökkentése. A konfliktushelyzetben a beavatkozás formája legnagyobb valószínűséggel direkt beavatkozás: a viselkedés leállítása vagy a konfliktusban levők szétválasztása. Ezeket a megállapításokat a pontos viselkedésformák beazonosítására alkalmas kódrendszerek alkalmazásával lehetett megtenni.

\subsection{Saját kódrendszer kialakítása}

Amennyiben mások által használt kódrendszereket nem találjuk megfelelőnek saját kérdésfeltevésünk szempontjából, akkor saját kódrendszert kell készítenünk. Ekkor is ajánlatos azonban irodalomkutatást végezni és áttekinteni, hogy más vizsgálatok tartalmaznak-e olyan kódokat, melyek részben beépíthetők saját kódrendszerünkbe. Az irodalomkutatás során tartsuk szem előtt, hogy mások kódrendszere milyen témára készült, milyen életkorú gyermekek megfigyelésére lett kialakítva, illetve a viselkedés szegmentálásának szintje hasonló-e az általunk alkalmazni kívánthoz.

A kódrendszerek eltérnek egymástól abban, hogy egy viselkedés leírására hány kódot használnak. Több dologtól függ, hogy hány kódot tartalmaz egy kódrendszer. Egyrészt kérdés, hogy a kódrendszer mennyire átfogó a viselkedésformák tekintetében (mi tartozik a témához?, átfogóan vagy szúken értelmezve ragadja meg a vizsgált viselkedést a kódrendszer?), másrészt kérdés, hogy milyen aprólékosan szegmentálja a viselkedést (hány kódot és milyen kódokat hoztak létre?). Ugyanaz a viselkedés megragadható egy kóddal (például utasít) vagy két kóddal (például tilt, illetve pozitív formában szólít fel). Hasonlóan, a szegmentálás aprólékosabb lesz, ha külön kódol- 
A kisgyermeknevelő-gyermek interakciók megfigyelésével kapcsolatos kihívások

juk a viselkedés verbális, illetve non-verbális vagy fizikai komponenseit. A szegmentálás szintjének beállításakor nem csupán az egyes kódok aprólékosságára kell odafigyelnünk, hanem arra is, hogy a kódrendszerünk különböző kódjai megközelítőleg azonos részletezettséggel ragadják meg a viselkedés elemeit.

A viselkedés kódokkal való leírásakor arról is döntést kell hoznunk, hogy mit tekintünk alapegységnek. Egyrészt gondolkodhatunk idői egységekben. Ekkor például másodpercenként, vagy 3,510 , 15, esetleg 30 vagy 60 másodpercenként írjuk le, hogy az adott időszakban mi az adott időszakra leginkább jellemző viselkedésforma, avagy ennyi másodpercenként készítünk „pillanatfelvételt” a viselkedésről.

Ha az időközönkénti „pillanatfelvételt” választjuk, akkor a megfigyelt viselkedéshez illeszkedjen az időbeli felbontás, azaz lehetőleg kevés olyan viselkedés legyen, melyet nem rögzítünk amiatt, hogy időben rövidebb, mint az általunk választott rögzítési ráta. Például, ha a gyermekek nagymozgását szeretnénk rögzíteni a bölcsődei csoportszobában, és $x$ másodpercenként készítünk pillanatfelvételt a csoportszobai pozíciójukról, akkor, ha 10 másodperces felbontást választunk, az alatt lehet, hogy egy gyermek a csoportszoba egyik feléből a másikba elmegy, majd eredeti pozíciójába visszatér, így a két egymást követő rögzítési pont az adott gyermeket közel ugyanazon a helyen találja. Ha azonban részletesebb az idői felbontás (3 vagy 5 másodpercenként történik a rögzítés), egy ilyen elmozdulást tetten tudunk érni.

Hasonló az elv akkor is, ha nem csupán a minden $\mathrm{x}$. másodpercben megfigyelhető viselkedést rögzítjük pillanatfelvételként, hanem az elmúlt x másodpercre jellemző viselkedésformát írjuk le. Ekkor azt a viselkedésformát fogjuk megnevezni, mely az eltelt idő több, mint felében látható volt. Itt a megfigyelt személyeinknél tipikusan előforduló viselkedésváltások sebességéhez kell igazítanunk a megfigyelés felbontását, hogy a megfigyelés gazdaságos legyen a lehető legkevesebb adatvesztés mellett.

A viselkedés leírásakor gondolkodhatunk viselkedési alapegységekben is. Ekkor azt rögzítjük, hogy a teljes megfigyelési időszakon belül milyen viselkedésformák, összesen milyen hosszban jelentkeztek, például, ha a gyermekek játékát figyeljük meg, akkor az egyes gyermekeknél milyen játékformákat láttunk. Ennél a megfigyelési formánál a tevékenységváltások jelzik, hogy más kódot kell adnunk a megfigyelt személyeknek. Különösen akkor működik jól ez a fajta kódolás, ha videós kódolóprogrammal dolgozunk, melyben a videó alatt egy idői síkon tudjuk jelölni az egyes viselkedéstípusokat, majd a program automatikusan összeszámolja a különböző kódok gyakoriságait és időtartamát, egymáshoz viszonyított százalékos arányát.

Hányféle kódra van szükségünk ahhoz, hogy le tudjuk írni a viselkedést? Erre leginkább az adatokban találjuk meg a választ. Például egész más kódokra lesz szükségünk akkor, ha atipikusan viselkedő anyákat figyelünk meg az Idegen Helyzet Tesztben, mintha képzett bölcsődei kisgyermeknevelőket veszünk videóra a bölcsődében. Noha mindkét esetben fontos lehet a válaszkészség, az előbbi esetben inkább van értelme az inszenzitív válaszformák keresésének, míg az utóbbinál a kódrendszerünknek inkább a szenzitív válaszok tekintetében kell differenciálnia. Logikailag vagy elméleti alapon ugyan felállíthatunk előre egy kódrendszert, azonban csak az adatokon kipróbálva látjuk, előfordul-e az adatokban az adott kódvariáció.

Lényeges szempont, hogy amennyiben egy főkategória vagy dimenzió alá több kód is tartozik, akkor ezek az alkategóriák egymást kölcsönösen kizáróak legyenek, például ha érzelmi állapotot kódolunk csecsemőknél, akkor az érzelmi állapotokon belül megkülönböztethetünk pozitív, semleges és negatív érzelmi állapotot (Remete, 2015).

Számolnunk kell azzal, hogy az adatokból kiinduló kódrendszer-fejlesztés körkörös jellegű lesz. Többszöri nekifutásra értjük meg saját kódjainkat, a kódolás szempontjai finomodnak a kódolás folyamata alatt.

A kódoláshoz érdemes kódkönyvet készíteni. Ebben szerepel a kódok hierarchiája, egymáshoz képesti viszonya, és meghatározásaik. Nem csupán a kódjainkat érdemes 
egyértelmű definícióval és a meghatározást alátámasztó példákkal ellátni, hanem a kódok közti különbségtételről is érdemes szólni főleg, ha vannak egymáshoz tartalmilag közel álló kódjaink.

\subsection{Kódolói megbizhatóság}

Amikor véglegesítettük a kódrendszert, megkezdődhet a kódolás, melynek megbízhatóságáról a vizsgálat közlésekor be kell számolnunk. A kódolók optimális esetben csak a kódrendszer használatát tanulják meg, sem a kutatási kérdés(eke)t, sem a vizsgálati csoportok jellemzőit és a vizsgálati személyek csoportba sorolását nem ismerik, ezáltal nem torzítják kimondatlan elvárásaik a kódolást. Ezt hívjuk „vak” kódolásnak. A vak kódolás biztosításához ügyelnünk kell arra, hogy a vizsgálati személyek személyazonosítói ne tartalmazzanak információt például a csoportba sorolásukról.

A kódolók olyan vizsgálati anyagon tanulják meg a kódrendszer használatát, mely nem része a megbízhatósági kódolás számítására szolgáló adathalmaznak. A betanításra érdemes több egyéni konzultációt tartani, hogy a kódolók magabiztosan tudjanak különbséget tenni a különböző kódok közt. Elsőként a kódkönyvvel érdemes megismertetni a kódolókat (tipikus példákat bemutatni az egyes kódokhoz a videóból), majd közösen kódolni, a kódok jelentését átbeszélni, majd ez alapján független kódolási feladatokat végezni. Ezt követően az ezekben előforduló típushibákat összegyűjteni és megbeszélni. A kódok elsajátítását tanulókártyákkal is segíthetjük. Mikor a másodkódoló a kódok kétharmadán 0,8 feletti ICC-értékkel kódol, áttérhetünk a független kódolásra.

A kódolás megbízhatóságát inter-rater és intra-rater reliabilitás számításával is ellenőrizzük Intraclass Correlation Coefficient (ICC) statisztikával. A kódolás megbízhatósága megfelelőnek tekinthető 0,75 érték felett (pl. Hallgren, 2012 és Koo E Li, 2016 szerint). A vizsgálatról szóló publikációban összesített ICC értéket szokás közölni, melynek kiszámításának módja akkor kérdés, ha több kóddal (illetve skálával vagy dimenzióval) dolgozunk a kódolás során. Az összesített ICC-érték megállapításához a skálánkénti ICC-adatok számtani kiátlagolása helyett a nyers adatokból számíthatjuk ki az összesített ICC-értéket. Ekkor a válaszegységenként párokba rendezzük a két kódolás összehasonlítandó értékeit (első kódolás - újrakódolás, illetve első kódoló - másodkódoló), és így számoljuk az összesített intraclass correlation coefficient értéket.

$\mathrm{Az}$ intra-rater reliabilitás az első számú kódoló önmagához képesti idői megbízhatóságát jelenti. Azaz a kódoló a teljes videós anyagot lekódolja, majd visszatér bizonyos random módon kiválasztott videófelvételekre, melyek kódolását megismétli. A többször kódolásra azért van szükség, hogy meggyőződjünk arról, hogy a kódok videóról-videóra való alkalmazása konzisztens.

$\mathrm{Az}$ inter-rater reliabilitás a másodkódoló és az első számú kódoló közti egyetértést jelenti. A másodkódoló nem szükséges, hogy a teljes vizsgálati anyagot lekódolja, a minta nagyságától függően a minta egynegyedeegyharmada elégséges.

\section{5. Összegzés}

Írásunk arra hívja fel a figyelmet, hogy mind a kisgyermekekkel foglalkozó szakemberek képzésének folyamatában, mind a pedagógiai vagy tudományos adatgyűjtés részeként, a megfigyelés figyelemre méltó eljárás. Tanulmányunkban összegyüjtöttük mindazokat a tudnivalókat, melyekre a megfigyelés tervezésekor érdemes gondolni. Noha a módszer idő- és energiaigényes, a megfigyelés révén részletgazdag és pontos információhoz jutunk a kisgyermekekről, és gondozóikkal való interakcióikról. Mindezek miatt az interakciók megfigyelése megkerülhetetlen.

\section{Köszönetnyilvánítás}

Tapasztalataim egy részét kurzusokon tanultam (2009-2018 közt). Doktori tanulmányaim keretében vehettem részt a Videotréning alapozó kurzusán, az AMBIENCE kódolói 
A kisgyermeknevelő-gyermek interakciók megfigyelésével kapcsolatos kihívások

képzésén, dr. Gervai Judit kötődés-megfigyelésről szóló kurzusán, illetve külföldi előadók pár órás workshopjain pl. Stupiggia, 2011. Doktori tanulmányaim lezárulta után 2018-ban volt lehetőségem a megfigyelés témájában rendezett Nemzetközi Pikler Szimpóziumon részt venni, illetve jelen lenni a Tardos Anna által vezetett „Megfigyelni és megismerni” c. szemináriumon. E tanulmány alapjául szolgáló további tapasztalatokat saját káromon tanultam meg a doktori kutatási anyagaim elemzése közben. Sokat tanultam témavezetőmtől, prof. Kalmár Magdától, illetve a témavezetőm korábbi és velem együtt végző doktoranduszaival és az ELTE Kognitív fejlődés programot végző doktoranduszokkal való eszmecseréből is, valamint a későbbiekben az ELTE Tanító- és Óvóképző Karán tanuló hallgatók megfigyelés módszerével dolgozó szakdolgozatainak témavezetéséből

\section{Felhasznált irodalom}

Bayer, C. L., Whaley, K. L. \& May, S. E. (1995): Strategic assistance in toddler disputes: II. sequences and patterns of teachers' message strategies. Early Education and Development, 6. 4. sz., 405-432.

Bodner, T. E. (2006): Designs, participants and measurement methods in Psychological research. Canadian Psychology, 47. 4. sz., 263-272. https://doi.org/10.1037/cp2006017

Bruce, T., Louis, S. \& McCall, G. (2014): Observing young children. Sage, London - Thousand Oaks -New Delhi - Singapore.

Clarke, J. (é.n.): Draft PICCOLO-B (for babies): Additional considerations for observations with infants 4-9 months old. New Mexico. URL:http://cdd.unm.edu/ecln/HVT/common/ pdfs/PICCOLO\%20Expansion\%20Notes.pdf

Crockenberg, S. \& Litman, C. (1990): Autonomy as competence in 2-year-olds: maternal correlates of child defiance, compliance, and self-assertion. Developmental Psychology, 26. 6. sz., 961-971. https://doi.org/10.1037/0012-1649.26.6.961

Degol, J. L. \& Bachman, H. J. (2015): Preschool teachers' classroom behavioral socialization practices and low-income children's selfregulation skills. Early Childhood Research
Quarterly, 31. 1. sz., 89-100.

https://doi.org/10.1016/j.ecresq.2015.01.002

Dowling, C. B., Smith Slep, A. M. \& O'Leary, S. G. (2009): Understanding preemptive parenting: relations with toddlers' misbehavior, overreactive and lax discipline and praise. Journal of Clinical Child \& Adolescent Psychology, 38. 6. sz., 850-857.

https://doi.org/10.1080/15374410903258983

Falus Iván (2014): A megfigyelés. In: Falus Iván; Tóth Istvánné Környei Márta; Bábosik István; Réthy Endréné; Szabolcs Éva; Nahalka István; Csapó Benő; Mayer Miklósné Nádasi Mária. Bevezetés a pedagógiai kutatás módszereibe. Elektronikus tananyag (6. fejezet): Budapest: Educatio Társadalmi Szolgáltató Nonprofit. URL: http://www.tankonyvtar.hu/en/tartlom/ tamop425/2011_0001_531_pedagogia/ch06.html

Feldman, R. (2012): Parenting behavior as the environment where children grow. In: L. C. Mayes \& M. Lewis, The Cambridge Handbook of Environment in Human Development. Cambridge University Press, Cambridge, 535-567.

Fukkink, R. G. \& Tavecchio, L. W. (2010): Effects of Video Interaction Guidance on early childhood teachers. Teaching and Teacher Education, 26. 8. sz., 1652-1659. https://doi.org/10.1016/j.tate.2010.06.016

Gombás Judit (2018): A videotréning módszer bemutatása, alkalmazásának lehetőségei a pedagógusképzésben. In: Karlovitz János Tibor (szerk.) Elmélet és gyakorlat a neveléstudományok és szakmódszertanok körébőll. International Research Institute sro., Komárom, 248-256.

Gyöngy Kinga (2017): Kezdö és tapasztalt kisgyermeknevelók viselkedésszabályozásának összehasonlitása. PhD-disszertáció. Budapest: ELTE PPK - Pszichológiai Doktori Iskola.

Hallgren, K. A. (2012): Computing Inter-Rater Reliability for observational data: An overview and tutorial. Tutorials in Quantitative Methods for Psychology, 8. 1. sz., 23-34. https://doi.org/10.20982/tqmp.08.1.p023

Hámori Eszter (2016): A korai kapcsolat zavarai. Pszichoanalizis, kötödéselmélet és csecsemökutatás a korai kapcsolati patológiák megértésében. Oriold és Társai Kiadó, Budapest.

Hámori Eszter és Rajnik Mária (2018. április 5.): A résztvevő csecsemő-megfigyelés speciális helyzetei: a videótechnika a kapcsolati folyamatok megértésében. Előadás. Nemzetközi Pikler Szimpózium: „Figyelj, hogy megértsd”. Nemzetközi Pikler Társaság, Budapest. 
Hédervári-Heller Éva (2008): A szülö-csecsemő konzultáció és terápia. A viselkedésszabályozás zavarai csecsemö- és kisgyermekkorban. Animula, Budapest.

Helmerhorst, K. O., Riksen-Walraven, J., Vermeer, H. J., Fukkink, R. G. \& Tavecchio, L. W. (2014): Measuring the interactive skills of caregivers in child care centers: development and validation of the Caregiver Interaction Profile Scales. Early Education and Development, 25. 5. sz., 770-790.

https://doi.org/10.1080/10409289.2014.840482

Herr, J. (2008): Working with Young Children (6.. kiad.). Goodheart-Willcox, Tinley Park. URL: https://www.g-w.com/pdf/sampchap 19781590708132_ch03.pdf

Hollway, W. (2012): Foreword. In C. Urwin \& J. Sternberg, Infant Observation and Research: Emotional Processes in Everyday Lives (XIVXV. old.). Routledge, Hove - New York.

Kochanska, G. \& Aksan, N. (1995): Mother-child mutually positive affect, the quality of child compliance to requests and prohibitions, and maternal control as correlates of early internalization. Child Development, 66. 1. sz., 236-254.

https://doi.org/10.2307/1131203

Kochanska, G., Aksan, N. \& Nichols, K. E. (2003): Maternal power assertion in discipline and moral discourse contexts: commonalities, differences, and implications for children's moral conduct and cognition. Developmental Psychology, 39. 6. sz., 949-963.

https://doi.org/10.1037/0012-1649.39.6.949

Kontos, S. (1999): Preschool teachers talk, roles and acivity settings during free play. Early Childhood Research Quarterly, 14. 3. sz., 363-382. https://doi.org/10.1016/S0885-2006(99)00016-2

Koo, T. K. \& Li, M. Y. (2016): A guideline of selecting and reporting intraclass correlation coefficients for reliability research. Journal of Chiropractic Medicine, 15. 2. sz., 155-163. https://doi.org/10.1016/j.jcm.2016.02.012

Kuczynski, L., Kochanska, G., Radke-Yarrow, M. \& Girnius-Brown, O. (1987): A developmental interpretation of young children's noncompliance. Developmental Psychology, 23. 6. sz., 799-806.

https://doi.org/10.1037/0012-1649.23.6.799

Kurki, K., Järvenoja, H., Järvelä, S. \& Mykkänen, A. (2016): How teachers co-regulate children's emotions and behaviour in socio-emotionally challenging situations in day-care settings.
International Journal of Educational Research, 76. (febr), 76-88.

https://doi.org/10.1016/j.ijer.2016.02.002

La Paro, K. M., Hamre, B. K. \& Pianta, R. C. (2012): Classroom Assessment Scoring System - Toddler Manual. Paul H. Brookes Publishing Company, Baltimore.

Laible, D. J. \& Thompson, R. A. (2002): Motherchild conflict in the toddler years: Lessons in emotion, morality, and relationships. Child Development, 73. 4. sz., 1187-1203. https://doi.org/10.1111/1467-8624.00466

Lekwa, A. \& Ysseldyke, J. (2010): Dissertation research in School Psychology: Changes in topics and methodology over the past 25 years. Journal of Applied School Psychology, 26. 1. sz., 17-37. https://doi.org/10.1080/15377900903386047

Maccoby, E. E. (1992): The role of parents in the socialization of children: an historical overview. Developmental Psychology, 28. 6. sz., 1006-1017. https://doi.org/10.1037/0012-1649.28.6.1006

Majorano, M., Corsano, P. \& Triffoni, G. (2015): Educators' intervention, communication and peers' conflict in nurseries. Child Care in Practice, 21. 2. sz., 98-113. https://doi.org/10.1080/13575279.2014.1001812

Martin, P. \& Bateson, P. (2007): Measuring behaviour. Az introductory guide. Cambridge University Press, Cambridge. https://doi.org/10.1017/CBO9780511810893

Milton, C., Kagan, J. \& Levine, J. A. (1971): Maternal control and obedience in the two-year-old. Child Development, 42. 6. sz., 1873-1894.

Parpal, M. \& Maccoby, E. E. (1985): Maternal responsiveness and subsequent child compliance. Child Development, 56. 5. sz., 1326-1334. https://doi.org/10.2307/1130247

Remete Eszter (2015): A csecsemőkori érzelemszabályozás kapcsolata a kötődéssel, temperamentummal és korai affektív környezettel. PhD-disszertáció. ELTE, Pszichológiai Doktori Iskola, Budapest.

Roggman, L. A., Cook, G. A., Innocenti, M. S., Norman, V. J., Christiansen, K. \& Anderson, S. (2013): Parenting Interactions with Children: Checklist of Observations Linked to Outcomes (PICCOLO): Paul H. Brookes Publishing, Baltimore.

Roggman, L. A., Cook, G. A., Innocenti, M. S., Vonda, J. N. \& Christiansen, K. (2013): Parenting interactions with children: checklist of observations linked to outcomes 
A kisgyermeknevelő-gyermek interakciók megfigyelésével kapcsolatos kihívások

(PICCOLO) in diverse ethnic groups. Infant Thomason, A. C. \& La Paro, K. M. (2009):

Mental Health Journal, 34. 4. sz., 290-306.

https://doi.org/10.1002/imhj.21389

Sallai Éva (2011): Osztálytermi interakciók elemzése. ELTE - Pedagógiai Doktori Iskola kurzusa a Magyar Videotréning Egyesülettel együttmüködésben, Budapest.

Schepers, Guy \& König, Claudia (2002): Családi videotréning. A családok segitésének új módszere. Animula, Budapest.

Stupiggia, M. (2011 március 22.): A családi interakciós minták videóval történö mikro-elemzése. A nonverbális kommunikáció jelentösége a családsegítés gyakorlatában. Előadás. ELTE-TÁTK, Budapest.

Szántó-Féder Ágnes (2017): Aktív gyerek, gondolkodó felnőtt. Syllabux, Budapest.

Tardos Anna (2018): Megfigyelni és megismerni. Szeminárium. Pikler Ház, Budapest.

Tardos Anna, Dehelán Éva és Szeredi Lili (1977): A szociális szabályok betartását célzó nevelöi magatartás. Magyar Pszichológiai Szemle, 34. 3. sz, 269-276.

Tassoni, P., Beith, K., Eldridge, H. \& Gough, A. (2002): Diploma in Child Care and Education. Heinemann, Oxford. Measuring the quality of teacher-child interactions in toddler child care. Early Education and Development, 20. 2. sz., 285-304. https://doi.org/10.1080/10409280902773351

Viaux-Savelon, S; Leclere, C; Aidane, E; Bodeau, N; Camon-Senechal, L; Vatageot, R; Feldman, R \& Cohen, D. (2014): Validation de la version française du Coding Interactive Behavior sur une population d'enfants à la naissance et à 2 mois. Neuropsychiatrie de l'Enfance et de l'Adolescence, 62. 1. sz., 53-60.

https://doi.org/10.1016/j.neurenf.2013.11.010

Wachs, T. D., Gurkas, P. \& Kontos, S. (2004): Predictors of preschool children's compliance behavior in early childhood classroom settings. Applied Developmental Psychology, 25. 4. sz., 439-357. https://doi.org/10.1016/j.appdev.2004.06.003

Williams, S. T., Mastergeorge, A. M. \& Ontai, L. L. (2010): Caregiver involvement in infant peer interactions: Scaffolding in a social context. Early Childhood Research Quarterly, 25. 2. sz., 251-266. https://doi.org/10.1016/j.ecresq.2009.11.004

\section{Challenges in observing caregiver-child interactions}

Observation is used for data collection in many sciences, including ethology, developmental psychology, and early childhood education. This paper aims to examine the observation of interactions between children and their caregivers in (a) clinical/therapeutic settings as well as in (b) early educational/pedagogical context and for (c) research purposes. Subsequently, the process of developing a code system is described. We review common pitfalls when coding observational data and present ways to avoid them. Observation can be time and energy consuming. Nevertheless, when compared with other research methods, it provides more detailed and accurate information about young children and their interactions with their caregivers. For all these reasons, observation of interactions is unavoidable and should be pursued.

Keywords: observation, interaction, research methods, ECEC, coding

Gyöngy Kinga (2019): A kisgyermeknevelö-gyermek interakciók megfigyelésével kapcsolatos kihívások. Gyermeknevelés, 7. 2-3. sz., 2-19. 